\title{
6 Conflicting professional identities for artists in transprofessional contexts
}

\author{
Insights from a pilot programme initiating \\ artistic interventions in organisations
}

\author{
Kai Lehikoinen, Anne Pässilä, and Allan Owens
}

\section{Introduction}

Traditionally, professional artists have spent years refining their professional skills for specific practices. Such education into specialised expertise has focused on investigating artistic ideas and expressing creativity, imagination, and emotion to create works of art for audiences to experience. While this continues to be of primary importance, the world of work for artists is changing. Artists are being called to work in unfamiliar settings and, for example, to collaborate in transprofessional contexts on the boundaries between professional disciplines where ideas from the arts cross-fertilise with expertise in other fields such as health care, social work, and business. Consequently, artists need to develop new professional skills and competencies integrated with their primary artistic ones, and an equally new understanding of what being an artist can be in the contemporary creative economy (Revelli, 2018; Hautamäki \& Oksanen, 2011). These demands inevitably raise questions about artists' professional identity, which we understand here as "professional self-concept based on attributes, beliefs, values, motives, and experiences" (Slay \& Smith, 2011, p. 86), and furthermore as a phenomenon that is complex, individual, affected by contextual circumstances, and inclined to transform over time (Sutherland \& Markauskaite, 2012).

Ariane Berthoin Antal (2015) acknowledges the challenge of professional identity issues when artists engage in artistic interventions in organisations. She argues that artists' professional identities and also responsibilities are geared towards some fundamental values in the arts, and that it is vital for artists to maintain such values as they collaborate with other professions. However, while it is important for artists to be in touch with their artistic orientation and identity when expanding their professionalism to work in new contexts, there is evidence that suggests that an overly fixed view of what constitutes being an artist can hinder such expansion. It is difficult enough within a single discipline to blend the roles of the artist, teacher, and researcher, as Alan Thornton (2013) states about emergent professionals in the field of arts education. It can be even more challenging to blend professional roles as one moves from the arts to work in a transprofessional mix of disciplines.

DOI: $10.4324 / 9781003108337-6$ 
In this chapter, we investigate the expanding professionalism of artists in the transprofessional realm of artistic interventions in organisations. In particular, we focus on artists wishing to bring their artistic thinking into organisation development and arts for wellbeing. We examine professional identity tensions that become evident in the self-reflective work of artists participating in a post-degree specialisation programme pilot "Artist as Developer: Artistic Interventions in Organisations" at the University of the Arts Helsinki (Uniarts) in 2014/2015. We investigate how these artists navigate multiple and at times conflicting identities within the challenges of working in unfamiliar transprofessional contexts.

We first introduce the specialisation programme. Then, we put forward our theoretical frames to study professional identities in the arts as dialogically constructed narratives vis-á-vis discursive power relations in the community of arts practitioners. The concept of "hybrid artist" is central to this discussion. Following that, we exemplify the hybrid work of some of the artists on the programme, as evidenced in their reflective reports, and the game-changing power that these revealed. We examine how these artists used their competencies to create new transprofessional spaces and in doing so helped people in organisations stretch their thinking. The concept of "third space" (Lehikoinen et al., 2015; Hulme et al., 2009 ) is used to refer to dialogical spaces in transprofessional contexts, which enable the co-creation of new ideas through co-reflection and cultural hybridisation. We then go on to draw out from the artists' self-reflective reports some of the emergent tensions in professional identity constructions that they experienced when moving to work in transprofessional contexts, and the implications of these. A final discussion section links our observations of identity conflicts to broader discourses about the purpose of the arts in contemporary societies.

\section{Specialisation studies for artists: A pilot programme on artistic interventions in organisations in Finland}

New training programmes in participatory arts and artistic interventions in organisations have been launched in Finland and elsewhere in recent years. The driver for introducing the pilot programme on artistic interventions at Uniarts was the legislation Government Decree on University Degrees and Specialisation Studies 1439/2014, requiring universities in Finland to prepare new specialisation studies in close collaboration with working life. The programme was based on research and development that was undertaken in three preceding projects focused on the arts in innovation processes. ${ }^{1}$ It was a concrete move towards expanding professionalism, creating an environment in which artists could renegotiate their work in contemporary societies. Rather than thinking about professionalism in the arts as something fixed, the programme conceived it as being socially constructed and evolving through social interaction both within and between particular domains (Kallunki \& Seppälä, 2016).

In the pilot, the participating artists had years of professional experience in, for example, acting, choreography, dancing, dramaturgy, music, performance art, painting, and light design. The aim of the programme was to provide the artists 
with competencies that they need to use their professionalism in transprofessional contexts and be able to design and apply what Berthoin Antal (2012) calls "artistic interventions in organizations" (see below). In addition, the programme sought to develop experience as "hybrid artists" (Abbing, 2002; Winkel, Gielen \& Zwaan, 2012), as the participants devised and facilitated artistic interventions as part of their internship in organisational contexts. These contexts included, for example, a nursing home, a psychiatric ward of a hospital, a church, an educational institution, a museum, an industrial organisation, and a municipality. The focus of their interventions ranged from service development and social interaction to risk-taking and experiential aspects of events, from value development to change facilitation and strengthening of wellbeing. The artists reflected on their experiences in these interventions in their reports, which were published in an anthology (Lehikoinen et al., 2016). It is through a close reading of this material that we then later investigated identity tensions for the artists.

\section{Hybrid artists: Dialogical construction of professional identities in undertaking artistic interventions in organisations}

Artists' work in hybrid contexts is nothing new as such. Camiel van Winkel, Pascal Gielen, and Koos Zwaan suggest that a "hybrid artist" blurs the boundaries of autonomous and applied arts practice and that such blending "is seen as a positive characteristic, as something that can contribute to the identity or the product of the artist in question" (2012, pp. 10-11, transl. KL). However, the concept of a hybrid artist is not just about multiple jobs and blurring of artistic approaches. It is also about crossing professional boundaries and entering new arenas to meet the growing needs for creativity, transprofessional collaboration, change, and wellbeing in organisations and society. Such new needs have opened up windows of opportunity for artists to expand their professional practices and contribute to a range of transprofessional contexts from education to organisational development and from health care to social innovations. Typically, such innovations call for expanding professionalism as they entail interdisciplinarity and cross-cultural pollination. That is, artists introduce ideas, concepts, approaches, and methods from the arts to establish a reciprocal process with other professionals to explore themes in organisational contexts where particular organisation cultures, professional discourses, and established ways of working prevail.

In organisational research, initiatives that bring in "people, products and practices from the world of the arts to stimulate learning and change in the organization" (Berthoin Antal, 2012, p. 45) have been referred to as "artistic interventions in organizations". As Berthoin Antal (2013) describes, artistic interventions come in multiple forms; their durations vary from a single session to long-term processes. They may engage artists from a range of artistic domains who contribute with "their aesthetic ways of knowing and doing, of engaging with people, ideas, artefacts and spaces" (Berthoin Antal, 2013, p. 8). Such interventions can serve a number of purposes, from building creative and inspiring environments to engaging with social responsibility, or from collaborative learning to the facilitation of 
transformation (Schiuma, 2011). Our view is that these initiatives entail a potential for cultural hybridisation between the expertise of the artist and respective participants, which can enable the emergence of "third spaces" (Hulme et al., 2009), cross-pollination of ideas, and collaborative learning leading to new insights and previously unrecognisable ideas unfolding for the particular organisation, its culture, and working practices. However, for artists to set up and facilitate interventions that enable genuine transprofessional collaboration requires more than core artistic skills. In our view, it requires understanding of collaborative learning, facilitation skills, and the ability to listen to the other-not a self-evident position for an artist who subscribes to the liberal humanist view of the artist as a selfcontained author.

Our understanding of professional identity in the arts draws on a recent reorientation in identity research and perceives it as a dynamic, dialogical process that is socially embedded and discursively constructed rather than a fixed and selfcontained whole (Bamberg et al., 2011; De Fina, 2011). The idea of a "dialogical self" decentres the "Cartesian self" of liberal humanism as self-contained, stable, and coherent. It refers to the idea that the sense of self (i.e. self-concept) has not only a temporal quality of the narrative - that is, stories of the self evolve in time and demand coherence (MacIntyre, 1984) — but also a spatial quality that entails positions and positionings in reference to the plurality of voices of the other that are often juxtaposed in the self. Also, the "I" can occupy many and even contradictory positions that can be in agreement or disagreement with each other in one person. That is, the self is conceived as a movement between "a multiplicity of positions among which dialogical relationships can be established ... [and where] collective voices, domination and asymmetry of social relations, and embodied forms of dialogue" (Hermans, 2001, p. 243) have significance. However, as we will point out later, the still prevalent liberal humanist view of the self with its striving towards a coherent narrative structure can underpin identity tensions as artists move to expand their professionalism in order to work in transprofessional contexts outside the traditional field of the arts.

In a dialogical process as described above, the artist's sense of self is constantly confronted with others in terms of "oppositions and compatibilities" (De Fina, 2011 , p. 271) that then inform ongoing identity construction in self-narratives. ${ }^{2}$ From such a perspective, communities of social interaction constitute "the site for the production of identities" (De Fina, 2011, p. 264). We regard "communities of practitioners" (Wenger, 2010) in the arts - including institutions of higher arts education - as such a site, where discursive power relations and related historical conceptions of the art and the artist accompanied by resistance to new ideas and changing values, not only regulate what can be meaningfully said and done, but also limit professional identities and practices. ${ }^{3}$ It is within such discursive complexity, and drawing on both imagination and alignment (Wenger, 2010), that artists come to construct their professional identities and position themselves in relation to the expanding world of the arts and its communities of artistic practice, which are impregnated with contradictory narratives and "murmur" (Gielen, 2015 , p. 22). Such identity work takes place, for example, in conversations with 
peers or when working on artistic portfolios, websites, funding applications, orin the case of our research - self-reflection in project reports. In each case, people position themselves differently depending on the situation as well as the social and power relations involved in reference to the utterances of the other and also of the imagined others in their "inner" dialogues (Hermans, 2001; Bakhtin, 1981) about themselves as artists and also about art.

A dominating discourse with which artists often align themselves, and that may become contested within the experience of hybrid work where artists engage transprofessionally, is that of autonomy and the "free" artist (Belfiore \& Bennett, 2008; Abbing, 2002; Becker, 1982). Such a discourse is embedded in the Renaissance idea of the artist as a genius with unique inborn creativity (Wolff, 1993 ) and the liberal humanist view of the self. It demands "true" artists to devote themselves to artmaking, free from restraints of society and without compromises (Becker, 1982). This liberal humanist view of the free and self-contained subject as the origin of a single meaning, which continues to underpin the modernist view of the artist, has been contested by post-structuralism, social constructionism, and some forms of feminism for more than half a century. ${ }^{4}$ These alternative perspectives, however, have not nullified the idea of "art for art's sake", as Berthoin Antal (2015) argues. Indeed, as any discipline, also the arts are entitled to define their central organising concepts, principles of procedure, criteria of success, and interests (Adshead, 1981; Pring, 1976) from within rather than from the viewpoint of some external determinants such as societal value creation, economic profitability, or popular taste. Further, for the arts to evolve and find unexpected new forms they need bold experimentation - as in basic research - free from external constraints.

In contrast to the narrative of artistic autonomy, however, new professional opportunities in the arts are increasingly underpinned by more instrumental or pragmatic narratives, which see the arts as a means to affect people and impact society. As Belfiore and Bennett (2008) point out, such narratives "should not just be seen as a recent and unwelcome encroachment of politics in the aesthetic sphere" (p. 190). Rather, they need to be regarded "as a mode of understanding" (p. 190) embedded deep in Western intellectual thinking. For centuries the arts, artistic thinking, creativity, and arts-based approaches have been used to generate individual and social impacts in a range of contexts. In the past two decades, however, artistic creativity has gained remarkable significance in policy papers and formal reports mainly for three reasons: first, the rise of the creative economy, second, the growing need for creativity and cultural competence in organisations, and, third, the growing need for all professionals to take part in tackling societal and other problems such as social exclusion, cultural tensions, health issues, and global warming.

\section{Artist-led interventions in organisations and their game-changing power}

To exemplify expanded work in transprofessional contexts, our attention now turns to the experiences of four artists - a theatre director, a performance artist, a 
dancer, and a dramaturg - who took part in the pilot programme at Uniarts. In our view, each of them used arts-led approaches to create third spaces for collaborative reflection and co-creation.

Miira Sippola is a theatre director with a second degree in religious studies. She devised an artistic intervention for Kallio Church, which is an Evangelican Lutheran church in the Kallio district of Helsinki in Finland. She describes how she used her theatre skills and dramatic understanding to challenge clergy and trigger improbable behaviours in church to investigate their relation to the church space as follows:

The priests and the deacons experimented with spatio-temporal perspectives: spatial relationships, kinaesthetic reactions, tempo, duration, form, repetition, paths, gestures, and architecture. These perspectives provided guided impulses to try different ways to move in the space, experiment with different postures, bodily shapes and combinations ... The aim ... was to get to know ... the church space, in "another way" and through play ... The experiments opened the perspective on how the church was used.

(Sippola, 2016, p. 113, transl. KL)

Performance artist Krista Petäjäjärvi facilitated an artistic intervention process in the New Club of Paris project for researchers of international intellectual capital. The New Club of Paris is an innovation network of scientists and entrepreneurs who support the societal transformation towards a knowledge society. Petäjäjärvi describes how imaginative acts based on performance art gave the participants an opportunity to step "across a boundary" (2016, p. 132, transl. KL) and expand their thinking in the innovation network as follows:

The group had ... created a fictive character, Veronica, that they used to process their solutions ... A volunteer from the group laid down on the table for others to draw the outline of her figure and wrote thought-voices for Veronica ... This "crucially different bodily way of being" was a turning point for the group after which the group work moved forward a great deal.

(Petäjäjärvi, 2016, p. 133, transl. KL)

Both of these projects offer examples of arts-based co-creative experimentation at play for members of a particular organisation to stretch their everyday thinking through arts-based activities. Such activities encourage discussion and encourage creative idea generation about workspace (in the case of Sippola) and teamwork (in the case of Petäjäjärvi), and also engender potential for new ways of working and interacting. While neither Sippola nor Petäjäjärvi use explicitly the concept of "third space" (Hulme et al., 2009), we suggest that its idea is implicitly materialised in the processes that they facilitate forming a creative dialogical space. Such space enables new perspectives to be constructed through the cultural hybridisation of artistic thinking embedded in the arts-based approach and the thinking of other professionals who participated, 
and the bodily experimentation, the co-creation of artistic outputs - drawings, writings, improvised performances, etc.- and the collaborative reflection of the process and its outputs. In other words, the artists' entry into the organisations set in motion processes of cultural hybridisation by blending approaches and ideas from theatre and performance art with professional practices of other fields to help the participants generate new insights about their workspace and teamwork.

Sippola as a theatre director co-creates with the clergy to generate a new social space, a third space (Hulme et al., 2009), which differs from the everyday of the church organisation. Such space enables the participants to explore their physical presence, their work and the mass as a social performance in the church space from fresh perspectives: "Incorporating such physical [activity] into delivering the mass strengthens it remarkably, gives extra boost to words, and heightens the spirit" (anonymous priest quoted in Sippola, 2016, p. 114, transl. KL). Likewise, Petäjäjärvi's intervention process creates a third space where the fundamentally different embodied way of being in the organisational space - i.e. the body on the table - together with the imagined character gives rise to the mixing of the two worlds: the organisational reality and the character's fictional reality. In the slightly strange and experimental "third space" the artists are able to use their expertise - corporeal, dramaturgical, and performative understanding of people in space and time - to encourage participants to reflect upon their work, challenge themselves, and test new approaches concerning work.

Petäjäjärvi reported on how a performative act challenged the limitations and possibilities of physical elements of a conventional organisational space: "If we always act physically in the same way ... sit on the chairs ... and look at the room in the same way, we can't expect for any new ideas to emerge" (Petäjäjärvi, 2016, p. 131, transl. KL). As one of the participants in Petäjäjärvi's intervention commented: "This room is not the same anymore" (anonymous as quoted in Petäjäjärvi, 2016, p. 131, transl. KL). The performative act opens up the room for new modes of thinking, or as Petäjäjärvi puts it: "To open up a space opens in us also a space for new ideas ... [and] softens the everyday [organisational] space" (2016, p. 131, transl. KL). Thus, co-creativity is stimulated in the participants by the artistic intervention, and generates added value in the form of new ideas within the organisation.

Sanna From is a dancer who worked as an artist in residence in an assisted housing unit for elderly people at Kontula Service Centre in Eastern Helsinki District. She describes the significance of the embodied work with the residents and the nursing staff as follows:

I believe that through the body we can reach each other ... and increase understanding of each other ... My ways of working were formed from dancing alone and together with the residents, attentive presence, discussion with the residents ... reminiscence, playing tricks, in other words common joy ... What emerged ... was based on improvisation ... when I met a 
resident in the corridor, we could first meet (verbally or non-verbally) and then move to bodily communication that often through touch led to a shared dance.

(From, 2016, pp. 59, 62-63, transl. KL)

The bodily aspects were relevant also for Sippola's intervention, which investigated the worship practice as a social performance as follows:

The actual exercises took place in two- or three-hour one-on-one sessions with each priest. The formula of the worship and the manual written for it established the foundation for the work. I encouraged and prompted the use of each liturgical gesture, breathing and the bodily presence. In many ways, the work was similar to theatre work between the director and the actor: it includes speaking, referring to meanings, committing to the persona of the other, encouraging her towards personalised expression.

(Sippola, 2016, p. 110, transl. KL)

Equally, Petäjäjärvi's intervention process had a strong bodily component, which involved touching and support, but in this case the aim was to strengthen peer support as follows:

I devised a frame for an exercise by telling that the exercise will be carried out if ... some of the group members feel that they now want to receive energy, power and support from the work community. The CEO came out voluntarily ... to lie down ... Everyone took the CEO from different parts of the body ... one, for example, supported the heel, the other, the third, and the fourth arm ... The guidance to the CEO was to feel to become supported, and to the rest of the group to carry and give their support.

(Petäjäjärvi, 2016, pp. 127-128, transl. KL)

The examples suggest that the bodily performances and social encounters that these artistic interventions in organisations made possible - and the collaborative reflection that they stimulated-helped the participants investigate central elements of their organisational practices and cultures in new artistic ways. Our close reading of all thirteen reports reveals that the artists used a range of competencies in their interventions, including multimethod painting, drawing, writing, documenting, performance practices, community arts practices, dramaturgy, body awareness techniques, solution-oriented methods of participatory drama, photography, word association, and poetry writing. The reports also suggest that the artists usually undertook a needs analysis at the site of the intervention and combined - in the process - a selection of artistic methods with reflective development methods such as the facilitation of group discussions and collaborative reflection, listening, observing, co-creating, sharing of experiences, and value discussions to address a range of topics that emerged from the interaction with the participants. 


\section{Lehikoinen et al.}

\section{Interpersonal challenges in facilitating collaborative reflection}

For us, the above suggests that devising and facilitating artistic interventions in organisations requires from artists not only artistic competence but also competence in facilitating reflective practice, which includes social skills, organising skills, analytical skills, and critical thinking. From's self-reflection goes further, to highlight the importance of the ability to use one's bodily presence intentionally, read the situation, and determine what actions or non-actions are needed with different people in particular contexts.

My ... role was to bring proximity and touch [into the community]. I tried to establish a bodily encounter with each of the residents. With some, it meant a particular greeting routine, with some others we always danced hand in hand. I took one person for rides on a wheelchair ... with someone else, I sat still as she pressed herself close to me. In general, I stroke their hair a lot, caressed hands, held shoulders, hugged, leaned, pulled, pushed, touched sore parts [of the body]. Or I was simply present somewhere nearby.

(From, 2016, p. 65, transl. KL)

Our reading of the artists' reports suggests that at least some of the interventions entailed an understanding of power relationships when it comes to setting up coreflective third spaces. For example, dramaturg Sussa Lavonen, whose intervention with staff members took place in the Department of Psychiatry at Helsinki University Hospital, reflects upon her work as follows: "The task is not to cut others off, demonstrate, teach let alone dictate. It is to be a listening, attracting and altruistic companion" (Lavonen, 2016, p. 238, transl. KL). For us, her account suggests that expanding one's professionalism in order to devise an artistic intervention in a hospital environment requires a form of pedagogy where an awareness of one's own power position and conscious use of low status is essential to create the democratic space for co-reflection and co-creation. Such awareness includes sensitivity to the ideologies that the artist brings into the organisation. Petäjäjärvi states:

As an artist in a work community, I am one of the factors that shape the relation to work and revising the work culture. Such work is connected to the idea of man and the ideology of the human being as a creature that possesses an enormous amount of creative capacity with which she can influence herself and the circumstances around her.

(Petäjäjärvi, 2016, p. 125, transl. KL)

Our analysis of the examples above suggests that artists can create third spaces for collaborative reflection and creation that have the potential to unsettle prevailing organisational conventions. However, to use their artistic skills and knowledge to stimulate such processes, sense the potential for change, and be sensitive to the way power circulates in organisations, they need competencies that stretch beyond core artistic competences and are embedded in both critical thinking and adult education. 


\section{Tensions in constructing professional identities for artists in contemporary transprofessional contexts}

In transprofessional contexts, the old ways of thinking about the arts and artistic work do not necessarily apply anymore. Indeed, as Bhabha has emphasised, "if you keep referring those new sites to old principles, then you are not actually able to participate in them fully and productively and creatively" (interviewed by Rutherford, 1990, p. 216). Yet, some of the self-narratives of the artists we studied suggest that they had difficulties in letting go of their preconceived ideas about what it means to be an artist in the 21 st century. For example, Sippola writes about her concerns regarding her new hybrid role that conflicted with her theatre director's identity as follows:

My doubts concerning ... the artist as a developer had many reasons. I felt that I will lose myself as an autonomous artist and that I will have to please others ... I was afraid that the "artist" ... disappears and the mere "developer" is amplified. Creative powers, that cannot be always controlled, belong to art. They demand the participants to throw themselves [into action], deep involvement and training in order to achieve results ... If the participants are not oriented in such a way, it may take energy from the artist-developer to persuade them and soften their attitudes. Of course, motivating is part of the theatre director's praxis as working with professionals. Nevertheless, I had my prejudices.

(Sippola, 2016, p. 106, transl. KL)

The excerpt above elucidates the tension in Sippola's self-reflection about positioning herself as a developer to work with an arts-based approach in an organisation (a church). Such a shift entails some concern about losing her professional identity as an artist. It could be suggested that underlying the identity tension that Sippola expresses is embedded, on one hand, in the traditional discourse of the artist as a "free" agent and the arts as the realm of powerful, and also to some extent uncontrollable, creativity. On the other hand, there is the utilitarian discourse of the artist as a "developer"- the idea, which is put forth increasingly by policy makers, funders, and researchers. When the utilitarian discourse enters the artist's self-narrative and clashes with the existing discourse on free agency there is a likelihood of identity conflict.

As noted earlier, liberal humanist ideas embedded in the project of modernity lead us to think that we are free-thinking individuals in our attempts to articulate our identity in the arts. However, such articulations are always socially conditioned and discursively regulated (Burr, 1995). While artists may not for the most part pay attention to the discourses that participate in forming their professional identities, such discourses become important, especially in times of change, as new ideas challenge established ways of acting and the clash generates tension (Jessop, 2002). In such turning points, as Sippola's account above suggests, artists are forced to reconsider their identity and negotiate their place in relation to the new narratives. To negotiate one's already existing professional identity 
in relation to a new discourse, and consequently also reconstruct and reorganise one's identity, may turn out to be a challenge due to discursive incompatibility, and also due to peer pressure of one's professional community. Especially so if oneself and the community members are inclined to subscribe to the liberal humanist view of the self and believe that professional identity needs to be a coherent whole.

\section{Discussion}

The world of the arts and its professional communities, which are permeated with contradictory narratives on art and the artist (Gielen, 2015), are in change at least partially due to the new opportunities that the growing need for arts-based thinking and creativity in organisations have generated (Danhash, 2018). This radical shift has brought about a need to consider what artists need beyond their core artistic competencies when their professionalism is expanding in the transprofessional boundary area between the arts and other professional fields. How do they work in such contexts, and what does such work mean in terms of their professional identity?

The excerpts of self-reflective reports of artists presented in this chapter demonstrate some of the ways in which identity and artists' work are interlinked, some of the tensions involved, and the discursive power that operates in such complexity. They also show how artists who bring their artistic expertise from dance, theatre, and performance art into various organisations can create a culturally hybrid space in which work-related questions can be explored from new perspectives to see things differently. Our analysis resonates directly with the definition of artistic interventions as a means to "make a difference" (Berthoin Antal et al., 2016, p. 3) in organisations. Such creative hybridity can generate a "third space" that Hulme et al. (2009) have discussed in relation to transprofessional practitioner enquiry.

However, the self-reflective reports examined extend understanding of artistic interventions in organisations and arts-based initiatives by highlighting corporeal, spatial, choreographic, dramaturgic, and performative aspects of such processes. In this regard, we claim that artists have the potential to shake conventional practices of being and belonging in organisations where relations are often formed through hierarchies, predefined work roles, and consensual ways of organising. Our analysis therefore suggests that artists need to develop social, pedagogical, analytical, and critical skills alongside their artistic expertise if they wish to expand their professionalism towards transprofessional realms.

Our analysis also suggests that a tension between the traditional discourse of the artist as a "free" agent and the utilitarian discourse of the artist as a developer, or a "hybrid artist" in organisations, can create doubts and identity conflicts in some artists as they consider expanding their professionalism. We would like to argue that the problem lies in the fact that artists who go to work beyond the traditional contexts of the arts are facing the need to navigate their professional identities in the context of a dominant modernist discourse and modernist institutions in the arts that prioritise the concept of "free" artist as genius, and values 
the autonomy of the arts above all else (Wolff, 1993). This inevitably challenges, and perhaps radically limits the space in which more complex and contextualised professional identities in the arts can be constructed. What is more, the modernist view of occupations taking place in coherent and self-contained "communities of practice" (Wenger, 2010) and "organisational silos" (Cilliers \& Greyvenstein, 2012) can hold back artists from seeing alternative, additional opportunities, and from using their full potential to make a living from the arts and to contribute to society. This, above all, if they are inclined to subscribe to the liberal humanist view of the self as a coherent whole.

What then makes the artist strive towards a compatible and coherent sense of professional identity? Drawing from MacIntyre's (1984) idea of narrative self and Wenger's (2010) idea of how people use alignment to identify with communities of practice, we argue that the structure of the narrative forces a particular logic of coherence upon the artist's identity reconstruction when alignment is taking place. In other words, artists may strive to present themselves as subjects that are congruent with their professional community of practice and the professional contexts that they are familiar with. That is, as the narrative structure demands unity, they try to construct their professional identity in ways that relate to existing stories about artists and art within the arts community that they are familiar with. However, when the artist decides to expand their professionalism in transprofessional contexts, the juxtaposition of narratives may entail a potential for conflicting narratives that can lead to an identity conflict, which we understand as a tension between the emerging new self-narrative and the socially dominant narratives in the arts that the self-narrative is expected to assimilate to. Thus, as artists - informed by the liberal humanist view of the self and the narrative coherence demand - strive to construct a coherent sense of professional identity, it can become hard for them to amalgamate self-narratives that are not compatible with each other: narratives that can co-exist only in a professional identity that is not coherent or fixed but instead complex, context-specific, and flexible. The problem, we suggest, is not the incompatibility of the self-narratives-for example, the narrative of the self as a free artist and the narrative of the self as an artsbased organisation developer - but rather the preconceived misconception that narratives that constitute our sense of identity need to fit together and establish a coherent whole.

Before we know how to act in transprofessional contexts in the boundary area between the arts and other fields, we need to understand that the narratives in which we belong are always discursive and context-specific. As such they both enable and limit our acting as professionals. As the arts have become an increasingly diversified domain, such narratives have become fluid and deterritorialised (Gielen, 2015). In the light of our research, we would like to suggest that in such complexity, resilience rather than rigidity - i.e. openness to multiplicity - in professional identification processes can be an advantage. This is something that, we think, programmes in higher arts education need to take seriously as they further enhance the preparedness of artists to contribute in transprofessional contexts and transform society. 


\section{Conclusion}

In this chapter, we have investigated the expanding professionalism of artists in the hybrid realm of artistic interventions in organisations. We have scrutinised how some artists have entered such a realm and, in doing so, articulated their approaches and navigated their professional identity. In addition, we have identified tensions between incommensurable discourses that may instigate identity conflict for artists as they move to work in transprofessional contexts outside the more traditional field of the arts. Our conclusion is that the work of artists in transprofessional contexts often entails the amalgamation of artistic competence with other competencies from a range of professional realms - especially critical thinking and adult education. Further, the process of expanding one's professionalism in hybrid transprofessional contexts may entail discourse tensions that can generate identity conflict for some artists. That is, preconceived views of the arts and the artist may challenge rather than encourage the learning of new professional artistic practice in such contexts.

As our analysis above suggests, border tensions between the arts as an independent realm and artists working in transprofessional contexts are underpinned by still dominating modernist views of the arts as autonomous and the artist as a "free" agent. Such views are not God-given truths but, instead, historically constructed, discursive ideals from a particular era in Western history. As professionalism in the arts expands and finds new arenas in transprofessional contexts, our conclusion is that to avoid unnecessary identity conflicts of artists in higher arts education it is all-important to make students aware of the historical specificity and cultural particularity of discourses that underpin artistic practices and the role of the hybrid artist in contemporary contexts, which are highly diverse and rapidly changing. As such diversity entails a range of motives, objectives, and approaches for artistic work that are not congruent with each other, it is crucial to break down binary oppositions that sustain false hierarchies in today's pluralistic art world. Therefore, it is imperative in higher arts education to discuss critically the relationship between professionalism in more traditional artistic practice and the expanding professionalism of hybrid artists in new transprofessional domains.

\section{Acknowledgements}

This work was supported by the ArtsEqual project, funded by the Academy of Finland's Strategic Research Council from its Equality in Society programme under Grant [number 314223/2017].

\section{Notes}

1 TAIKA I (2008-2011) addressed art as an interface for cross-sectoral cultural innovations, TAIKA II (2011-2013) investigated art as a means to improve the quality of work life and innovation capability in organisations, and Training Artists for Innovation (2011-2013) provided a competence frame and curriculum guidelines for the programme. 
2 It is such self-narratives that materialise in the artists' self-reflection reports explored later in this chapter.

3 See Renshaw (2005). On the relations between discourse, power and the self, see e.g. Burr (1995).

4 See e.g. Box (2011); Burr (1995); Butler (1990).

\section{References}

Abbing, H. (2002). Why Are Artists Poor? The Exceptional Economy of the Arts. Amsterdam University Press.

Adshead, J. (1981). The Study of Dance. Dance Books.

Bakhtin, M. M. (1981). The Dialogical Imagination. Four Essays by M.M. Bakhtin (C. Emerson \& M. Holquist, Transl., M. Holquist, Ed.). University of Texas Press.

Bamberg, M., De Fina, A. \& Schiffrin, D. (2011). Discourse and identity construction. In S. Schwartz, K. Luyckx \& V. Vignoles. (Eds.), Handbook of Identity Theory and Research (pp. 177-199). Springer.

Becker, H. S. (1982). Art Worlds. University of California Press.

Belfiore, E. \& Bennett, O. (2008). The Social Impact of the Arts: An Intellectual History. Basingstoke: Palgrave Macmillan.

Berthoin Antal, A. (2012). Artistic intervention residencies and their intermediaries: A comparative analysis. Organization Aesthetics, 1(1), 44-67.

Berthoin Antal, A. (2013). Art-based research for engaging not-knowing in organizations. Journal of Applied Arts \& Health, 4(1), 67-76.

Berthoin Antal, A. (2015). Artistic interventions in organizations: Beyond the fad. In A. Örtenblad (Ed.), Handbook of Research on Management Ideas and Panaceas: Adaptation and Context (pp. 320-337). Edward Elgar.

Berthoin Antal, A., Woodilla, J., \& Johansson Sköldberg, U. (2016). Artistic interventions in organisations introduction. In U. Johansson Sköldberg, J. Woodilla \& A. Berthoin Antal (Eds.), Artistic Interventions in Organizations: Research, Theory, Practice (pp. 3-17). Routledge.

Box, C. (2011). Subjectivity after Wittgenstein: The Post-Cartesian Subject and the "Death of Man". Continuum.

Burr, V. (1995). An Introduction to Social Constructionism. Routledge.

Butler, J. (1990). Gender Trouble: Feminism and the Subversion of Identity. Routledge.

Cilliers, F. \& Greyvenstein, H. (2012). The impact of silo mentality on team identity: An organisational case study. SA Journal of Industrial Psychology/SA Tydskrif vir Bedryfsielkunde, 38(2), Art. \#993. doi:10.4102/sajip.v38i2.993

Danhash, N. (2018). The world of work. In B. Revelli (Ed.), Careers in the Arts: Visions for the Future (pp. 11-15). ELIA.

De Fina, A. (2011). Discourse and identity. In T. A. Van Dijk (Ed.), Discourse Studies: A Multidisciplinary Introduction ( $2^{\text {nd }}$ ed.) (pp. 263-282). Sage.

From, S. (2016). Tanssi meille-Taiteilijaresidenssissä Kontulan palvelukeskuksen ryhmäkodissa. In K. Lehikoinen, A. Pässilä, M. Martin \& M. Pulkki (Eds.), Taiteilija kehittäjänä: taiteellisetinterventiot työssä (pp.59-70). Taideyliopiston Teatterikorkeakoulu.

Gielen, P. (2015). The Murmuring of the Artistic Multitude: Global Art, Memory and PostFordism ( $3^{\text {rd }}$ ed.). Valiz.

Hautamäki, A. \& Oksanen, K. (2011). Tulevaisuuden kulttuuriosaajat: näkökulmia moderniin elämään ja työhön. Eduskunnan tulevaisuusvaliokunnan julkaisuja 5/2011. Eduskunnan tulevaisuusvaliokunta. 
Hermans, H. J. M. (2001). The dialogical self: Toward a theory of personal and cultural positioning. Culture \& Psychology, 7(3), 243-281.

Hulme, R., Cracknell, D. \& Owens, A. (2009). Learning in third spaces: Developing trans-professional understanding through practitioner enquiry. Educational Action Research, 17(4), 537-550.

Jessop, B. (2002). The Future of the Capitalist State. Polity Press.

Kallunki, J. \& Seppälä, H. (2016). Korkeakoulujen erikoistumiskoulutukset. Käsikirja koulutusten kehittäjille. Arene \& Unifi.

Lavonen, S. (2016). Haluatko vastata vai vastauksia?. In K. Lehikoinen, A. Pässilä, M. Martin \& M. Pulkki (Eds.), Taiteilija kehittäjänä: Taiteelliset interventiot työssä (pp. 237-252). Taideyliopiston Teatterikorkeakoulu.

Lehikoinen, K., Pässilä, A. \& Owens, A. (2015, April 11). Critical reflection and the arts as third spaces. [Conference paper]. OLKC Conference, Milan, Italy.

Lehikoinen, K., Pässilä, A., Martin, M. \& Pulkki, M. (Eds.) (2016). Taiteilija kehittäjänä: taiteelliset interventiot työssä. Taideyliopiston Teatterikorkeakoulu.

MacIntyre, A. (1984). After Virtue: A Study in Moral Theory ( $3^{\text {rd }}$ ed.). University of Notre Dame Press.

Petäjäjärvi, K. (2016). Mitä performanssitaiteilija tekee toimistossa? Performanssi taiteellisen intervention välineenä. In K. Lehikoinen, A. Pässilä, M. Martin \& M. Pulkki (Eds.), Taiteilija kehittäjänä: taiteelliset interventiot työssä (pp. 23-138). Taideyliopiston Teatterikorkeakoulu.

Pring, R. (1976). Knowledge and Schooling. Open Books.

Renshaw, P. (2005). Connecting conversations: The changing voice of the artist. In M. Miles (Ed.), New Practices-New Pedagogies: A Reader (pp. 81-96). Routledge.

Revelli, B. (Ed.) (2018). Careers in the Arts: Visions for the Future. ELIA.

Rutherford, J. (1990). The third space: Interview with Homi K. Bhabha. In J. Rutherford (Ed.), Identity: Community, Culture, Difference (pp. 207-221). Lawrence and Wishart.

Schiuma, G. (2011). The Value of Arts for Business. Cambridge University Press.

Sippola, M. (2016). Teatteriohjaajan interventio kirkossa. In K. Lehikoinen, A. Pässilä, M. Martin \& M. Pulkki (Eds.), Taiteilija kehittäjänä: taiteelliset interventiot työssä (pp. 105-121). Taideyliopiston Teatterikorkeakoulu.

Slay, H. S. \& Smith, D. A. (2011). Professional identity construction: Using narrative to understand the negotiation of professional and stigmatized cultural identities. Human Relations, 64(1), 85-107.

Sutherland, L. \& Markauskaite, L. (2012). Examining the role of authenticity in supporting the development of professional identity: An example from teacher education. Higher Education, 64(6), 747-766.

Thornton, A. (2013). Artist, Researcher, Teacher. A Study of Professional Identity in Art and Education. Chicago University Press.

Wenger, E. (2010). Communities of practice and social learning systems: The career of a concept. In C. Blackmore (Ed.), Traditions of Understanding: Language, Dialogue and Experience (pp. 179-198). Springer.

Winkel van, C., Gielen, P. J. D. \& Zwaan, K. (2012). De hybride kunstenaar. De organisatie van de artistieke praktijk in het postindustriële tijdperk. AKV/St. Joost.

Wolff, J. (1993). The Social Production of Art ( $2^{\text {nd }}$ ed.). Macmillan. 